\title{
Patient's health problems after injury-related damage of cervical spine
}

Problemy zdrowotne pacjenta po urazowym uszkodzeniu kręgosłupa na wysokości kręgów szyjnych

\section{Jolanta Sułekk ${ }^{1,2,3}$, Maria Półtorak², Katarzyna Pańtak²}

\author{
${ }^{1}$ Uniwersytecki Szpital Ortopedyczno- Rehabilitacyjny w Zakopanem/The Orthopedic-Rehabilitation University Hospital in Zakopane \\ 2PPWSZ w Nowym Targu/Podhale State College of Applied Sciences in Nowy Targ \\ ${ }^{3}$ Wydział Nauk o Zdrowiu, Uniwersytet Jagielloński w Krakowie/Faculty of Health Sciences, The Jagiellonian University in Cracow
}

CORRESPONDING AUTHOR/AUTOR DO KORESPONDENCJI:

Jolanta Sułek

ul. Kowaniec 107, 34-400 Nowy Targ e-mail: jola.sulek@ poczta.fm

\section{STRESZCZENIE}

Słowa kluczowe:

\section{ABSTRACT}

Key words:

\section{PROBLEMY ZDROWOTNE PACJENTA PO URAZOWYM USZKODZENIU KRĘGOSLUPA NA WYSOKOŚCI}

\section{KREEGOWW SZYJWYCH}

Materiał i metody. W artykule opisano przypadek pacjenta hospitalizowanego w Uniwersyteckim Szpitalu OrtopedycznoRehabilitacyjnym z powodu uszkodzenia rdzenia kręgowego i kręgosłupa w odcinku szyjnym.

Metoda - studium przypadku. Posłużono się techniką analizy dokumentacji medycznej, w tym: Kart Intensywnego Nadzoru i raportów lekarskich i pielęgniarskich.

Celem pracy była ocena wpływu urazu kręgosłupa w odcinku szyjnym na problemy pielęgnacyjne pacjenta hospitalizowanego w oddziale intensywnej terapii w stanie zagrożenia życia.

Streszczenie. W niniejszej pracy opisano przypadek trzydziestosześcioletniego pacjenta z urazowym złamaniem szyjnego odcinka kręgosłupa i porażeniem czterokończynowym z powodu ucisku i ognisk niedokrwienia rdzenia kręgowego w odcinku szyjnym. Na podstawie analizy dokumentacji oraz obserwacji własnych w artykule przedstawiono model procesu pielęgnowania dostosowanego do problemów pojawiających się u pacjenta. W trakcie hospitalizacji zaobserwowano typowe powikłania: infekcje układu oddechowego, odleżyny, zaburzenia elektrolitowe, oraz zaburzenia elektrycznej pracy serca i zaburzenia emocjonalne wynikające z urazu, ale też będące prawdopodobnie następstwem stresu pourazowego.

urazy kręgosłupa, problemy pacjenta, opieka pielęgniarska

\section{PATIENT'S HEALTH PROBLEMS AFTER INJURY-RELATED DAMAGE OF CERVICAL SPINE}

In the following review there is described the case of 36-year-old patient with trauma-related fracture of cervical spine followed by tetraparesis resulting from compression and ischaemia foci of cervical spinal cord. On the basis of medical record's analysis as well as on observation made by authors, the model of nursing process adjusted to patient's needs is described in this article. In the course of hospitalization the typical complications were observed: respiratory tract infections, bedsores, water-electrolyte imbalances, arrhythmias, emotional disturbances resulting not only from injury but also, with high probability, as aftermath of post-traumatic stress.

Material and methods. This paper discusses the case of a patient who was hospitalized at the University Orthopedic and Rehabilitation Hospital due to cervical spine and spinal cord injury.

Method - a case study.

Medical documentation was analyzed, including Intensive Care Unit (ICU) information cards and doctor and nurse reports. The purpose of this work was to assess the impact of cervical spine injury on nursing problems with a patient admitted to ICU under life-threatening conditions.

Summary. This paper discusses the case of a 36-year-old patient with a broken cervical spine and a tetraplegia resulting from pressure and foci of ischemia in the cervical spine region. This article presents a nursing model, accounting for the problems specific to this patient, that is based on the analysis of medical documentation and observation. During hospitalization typical complications were observed - infections of the respiratory system, bedsores, electrolyte disruption, disruption of the electrical activity of the heart, emotional disturbance resulting from the injury, but also likely being post-traumatic stress disorder (PTSD) in nature.

spinal injury, patient health problems, nursing 


\section{INTRODUCTION}

Injuries of the spine and spinal cord are serious medical problems. Severe trauma, especially to the cervical section, usually results in permanent disability. It is often caused by road accidents, falls from heights, penetrating trauma, sport injuries, and the victims are predominantly young people in good health. Such injuries can occur at any age, but the average is observed between 16 and 40 years of age. The most common mechanism of injury to the cord is breaking or twisting of the spine. Secondary damage to the spinal cord is caused by pressure on bone elements and intervertebral discs, extravasated blood $[1,2]$. A direct result of spinal injury may also be spinal shock. This is a temporary absence of spinal reflexes below the level of injury, usually lasting from seconds up to several weeks. It is characterized by flaccid paralysis of muscles below the level of injury, which, after several weeks, changes into uncontrollable, reflexively increased muscle tension [3]. The symptoms of spinal injury depend on the location, extent and type of trauma. Damage between medulla oblongata and $\mathrm{C} 3$ results in sudden circulatory and respiratory arrest. Damage between C3 and C5 weakens or completely shuts off respiratory action of the diaphragm and intercostal muscles, which severely impairs breathing. Damage to the thoracic spine causes pain and (or) disruption of sensation in the area of the corpus, while damage to the conus medullaris results in sphincter problems $[3,4]$.

Following injury patients are usually in physical and mental shock, some even in an altered mental state. They are terrified by their own physiological response and their situation, which amplifies the feeling of loss of control over their situation. Physiological and emotional chaos deepens. Symptoms such as hyper-stimulation, increased heart-rate (or, paradoxically, lowered heart-rate) difficulty breathing, all aggravate the fear response, panic and hypertension [5]. Post-traumatic stress disorder (PTSD) results from exposure to a stressful event or situation. Such a situation could cause extreme terror in any person [5]. PTSD may be caused by any event involving injury, a life-threatening situation which alters the way a person thinks, alters their emotions and behaviours [5].

\section{Description situations patient's health}

The patient described here is a young, 36-year-old male. He had an accident while working in a forest. He was crushed by a felled tree. His condition upon admission was categorized as serious. The diagnosis was a broken cervical spine, tetraplegia, and subcapsular splenic rapture. Fluctuation of consciousness was also observed. Flaccid paralysis of legs and partial paralysis of arms were also diagnosed during admission. The upper limbs paralysis occurred distally below the elbow. The patient's respiration and cardiovascular action were stable, he was conscious but with signs of confusion. He had visible abrasions of the skin on his face and broken teeth. The state of hygiene was determined to be poor. Independently of the injuries to the teeth due to the accident, it was observed that the state of oral hygiene was insufficient and there was caries present, which, as it turned out later, was important during subsequent hospitalization.
Urgent surgery was performed, which involved decompression of the spinal tube in the cervical section and the stabilization of the fracture of C6-C7 with anterior and posterior access, using titanium components. The surgery was performed under general anesthesia. Intubation was difficult due to the nature of the injury. It was, however, free of complications. The patient was intubated using a reinforced endotracheal tube. Sings of neurogenic shock were observed during the procedure. Fluid therapy and dopamine infusion were applied. Between stages 1 and 2 of the procedure a failed attempt was undertaken to gain central access to the right internal jugular vein. Access was gained to the right subclavian vein. During surgery the patient lost $700 \mathrm{ml}$ of blood. After awakening still in the operating theatre, the patient was able to move his upper limbs symmetrically. After assessing the mobility and sensation in the upper limbs (wake-up-test), he was sedated again and turned over to ICU for cardio-respiratory stabilization. After the surgery the patient was put on the respirator in volume-controlled SIMV mode. The cervical spine was secured using a Schantz-type neck collar.

During treatment the patient was repeatedly extubated and intubated due to growing concerns about signs of respiratory failure. The coughing reflex was weak due to paralysis. There was a large amount of mucus in the respiratory tract, which the patient was unable to expectorate.

In the end, a tracheostomy was performed. After a few weeks the patient did not require the respirator. It was necessary to remove the mucus from the respiratory tract by suction periodically. The patient was concerned with his inability to expectorate on his own. Additionally, he felt discomfort from the pressure caused by the band affixing the tracheostomy tube. The patient reported dyspnoea. He was concerned that the tube was not properly attached.

The patient displayed anxiety when he lost sight of his carer. He demanded his body position to be changed every few minutes. At night he tried to ward off sleep, as he was afraid the hospital staff might not notice potential life-threatening symptoms.

Signs of allopsychic disorientation were observed. The patient was agitated. It was impossible to engage him in logical interaction.

Due to cardio-vascular distress, an infusion of catecholamines was maintained for 4 days. Repeated intermittent bradycardia and one episode of supraventricular tachycardia (approx. 200/min.) were observed, whose etiology were unknown. During hospitalization an asystolic cardiac arrest occurred. The patient was successfully resuscitated.

While in ICU, cultures were grown from the mucus in the patient's bronchi: Pseudomonas aeruginosa, S. epidermidis, C. albicas, Acinetobacter haemoliticus. Targeted antibiotic therapy was implemented.

During hospitalization the patient was initially fed through a tube, and periodically entirely intravenously. Disruptions within the digestive tract were observed as caused by not only the injury but also the treatment and method of feeding. As a result of using industrial mixes for feeding the patient, initially an absence of peristalsis was observed, followed by diarrhea and tarry stool. Despite balanced nutrition therapy, there were complications 
indicating malnutrition: bedsores in the waist area, suppressed immunity, anaemisation.

The patient received dental, surgical and laryngological consultation. Additional disorders were observed in the form of hyponatremia and polyuria. First attempts at upright standing resulted in fainting.

Before being discharged form ICU the patient was conscious and in logical contact. Due to the presence of the tracheostomy tube he communicated via lip movement and voiceless whisper. He did not report problems, did not have a fever, his respiration was stable, and he periodically required removal of mucus from the respiratory tract. He had full sensation above the navel, and the sensation below was present but considerably weakened. His legs remained paralyzed.

The patient had good circulation, his blood pressure was stable. Mobility of the upper limbs was possible within the shoulder area, the strength and tension of muscles were weakened.

During hospitalization his neurological state was improved as regards the sensation and mobility of the upper limbs. The post-surgery wound healed, the patient underwent the initial cycle of rehabilitative therapy. Of the current problems the ones that remained were bedsores, trouble sleeping, occasional dyspnoea and emotional disturbances. The patient was transferred to the rehabilitation ward in a stable condition for further treatment.

Recommendation upon discharge from ICU:

- upright standing 4 times daily, following the administration of Effortil to prevent orthostatic hypotension

- remaining in a sitting position for one hour daily, gradually extending the time

- removal of mucus from upper respiratory tract

- maintenance of tracheostomy tube

- administration of oral medication

Nursing problems occurring during hospitalization in ICU:

1. Difficulty in maintaining clear airways due to a large amount of thick, purulent mucus, disturbed breathing, aspiration, dyspnoea, migration of mucus to nasopharynx, hissing, obstruction of airways, impaired gas exchange.
2. The risk of complications resulting from tracheotomy and mechanical ventilation, e.g. aspiration of food into airways, hemorrhaging, stenosis of the trachea, infection, esophageal fistula.

3. Increased perspiration due to fever, impaired thermoregulation, electrolyte imbalance, dehydration, $\mathrm{PH}$ imbalance.

4. The risk of vascular complications due to central venous catheter (e.g. an inflammation of the point of entry, clotting in the catheter).

5. The risk of urinary tract infection due to catheter.

6. The risk of complications due to enteral feeding, e.g. obstruction of the tube, infection, nausea, vomiting, flatulence, diarrhea.

7. Impaired verbal communication due to tracheostomy tube, mechanical ventilation and sedation.

8. The risk of complications from lack of mobility, e.g. bedsores, sore spots, venous thromboembolism, malformation of joints, muscle atrophy.

9. Deficits in self-care due to the condition of the patient, fluctuating consciousness, artificial ventilation and sedation.

10. Mental disturbance.

11. Decubitus in the area of the hip belt caused by malnutrition.

\section{SUMMARY}

Nursing problems presented in this article occur in the majority of patients with spinal injury. Additionally, in this case PTSD-type problems were observed. During the patient's stay in ICU these were the predominant problems for an extended period of time: anxiety, insomnia, heart rate problems. One might conclude that in ICU not enough attention is paid to the mental state of patients. This is perhaps the result of insufficient training of the nursing staff, inadequate staffing or a lack of clinical psychologists. Problems with the respiratory system were caused by spine injury (shallow breathing, difficulty expectorating) and insufficient oral hygiene aggravated the problems. This was one of the main reasons for the patient's extended hospitalization, and the escalation of therapeutic problems [6-14].

\section{Problemy zdrowotne pacjenta po urazowym uszkodzeniu kręgosłupa na wysokości kręgów szyjnych}

\section{WPROWADZENIE}

Urazy kręgosłupa i rdzenia kręgowego stanowią poważny problem medyczny. Ciężkie urazy, zwłaszcza w odcinku szyjnym najczęściej powodują trwałe kalectwo. Częstymi przyczynami są wypadki komunikacyjne, upadki z wysokości, urazy przenikające, kontuzje sportowe, a ofiarami najczęściej są osoby młode, dotychczas zdrowe. Do tak poważnych obrażeń może dojść w każdym wieku, jednak średnia wieku dotyczy osób od 16 do 40 roku życia. Najczęściej mechanizm uszkodzenia rdzenia związany jest ze złamaniem lub zwichnięciem kręgosłupa. Wtórne uszkodzenia rdzenia kręgowego spowodowane są uciskiem elementów kostnych, krążków międzykręgowych, wynaczynionej krwi [1,2]. Bezpośrednim następstwem urazowego uszkodzenia rdzenia kręgowego może być także szok rdzeniowy. Jest to czasowe, trwające od kilku sekund do kilku tygodni zniesienie odruchów rdzeniowych poniżej poziomu uszkodzenia rdzenia. Charakteryzuje go 
wiotkie porażenie mięśni poniżej poziomu uszkodzenia, który po kilku tygodniach lub miesiącach przechodzi w nie poddające się kontroli, odruchowo wzmożone napięcie mięśni [3]. Objawy urazu rdzenia kręgowego zależą od miejsca, rozległości i rodzaju uszkodzenia. Uszkodzenie między opuszką rdzenia i C3 powoduje nagłe zatrzymanie krążenia i oddechu. Uszkodzenie w odcinku C3 - C5 osłabia lub całkowicie wyłącza czynność oddechową przepony i mięśni międzyżebrowych, znacznie upośledzając oddychanie. Uraz w odcinku piersiowym powoduje ból i (lub) zaburzenie czucia w obrębie tułowia, a uszkodzenie stożka końcowego - zaburzenia zwieraczy $[3,4]$. Bezpośrednio po traumatycznym wydarzeniu ofiary znajdują się w stanie fizycznego i psychicznego szoku, niektóre nawet w odmiennym stanie świadomości. Są przerażone własnymi reakcjami psychofizjologicznymi oraz sytuacją, co wtórnie wzmacnia u niektórych $\mathrm{z}$ nich poczucie utraty kontroli nad sytuacją. Pogłębia się fizjologiczno - emocjonalny chaos. Objawy, jak: nadmierne pobudzenie, przyspieszony rytm pracy serca (lub paradoksalnie zwolniony), problemy z oddychaniem - tylko nasilają reakcje strachu, paniki i nadmiernego napięcia [5]. Zespół stresu pourazowego (PTSD) jest następstwem ekspozycji na zdarzenie lub sytuację stresującą. Taka sytuacja wywołałaby skrajnie przerażające przeżycia u prawie każdego człowieka [5]. Zespół stresu pourazowego może zostać spowodowany przez dowolne doświadczenie, związane z urazem i przeżyciem sytuacji grożącej ofierze, które zmienia ludzkie myślenie, emocje i zachowania [5].

\section{Opis sytuacji zdrowotnej pacjenta}

Opisywany pacjent jest młodym trzydziestosześcioletnim mężczyzną. Uległ wypadkowi podczas pracy w lesie. Został przygnieciony przez ścinane drzewo. Jego stan zdrowia podczas przyjęcia oceniono jako ciężki. Rozpoznano złamanie kręgosłupa w odcinku szyjnym, czterokończynowe porażenie i podtorebkowe pęknięcie śledziony. Zaobserwowano również zaburzenia świadomości. W trakcie przyjęcia u pacjenta zdiagnozowano: porażenie wiotkie kończyn dolnych i niepełne kończyn górnych. Porażenie kończyn górnych występowało dystalnie poniżej stawów łokciowych. Pacjent był krążeniowo i oddechowo wydolny, przytomny, z cechami splątania. Widoczne były otarcia skóry twarzy, złamane zęby w łuku szczęki. Stan higieniczny pacjenta oceniono jako zły. Niezależnie od uszkodzeń zębów spowodowanych wypadkiem zaobserwowano niedostateczny stan higieniczny jamy ustnej i zmiany próchnicze, co - jak się później okazało miało znaczenie podczas dalszej hospitalizacji chorego.

W trybie pilnym wykonano zabieg operacyjny polegający na odbarczeniu kanału kręgowego w odcinku szyjnym ze stabilizacją złamania C6- C7 z dostępu przedniego i tylnego na instrumentarium tytanowym. Zabieg wykonano w znieczuleniu ogólnym złożonym. Intubacja była utrudniona ze względu na charakter urazu. Przebiegła bez powikłań. Pacjent został zaintubowany zbrojoną rurką intubacyjną. W trakcie zabiegu wystąpiły cechy wstrząsu neurogennego. Zastosowano intensywną płynoterapię i wlew dopaminy. W przerwie między pierwszym i drugim etapem zabiegu podjęto nieudaną próbę uzyskania dostępu centralnego dożylnego przez prawą żyłę szyjną wewnętrzną. Uzyskano dostęp do prawej żyły podobojczykowej. W czasie zabiegu pacjent stracił $700 \mathrm{ml}$ krwi. Po wybudzeniu na sali operacyjnej symetrycznie poruszał kończynami górnymi. Po ocenie ruchomości i czucia w kończynach (wake-up-test) został wtórnie sedowany i przekazany na oddział intensywnej terapii celem stabilizacji krążeniowo - oddechowej. Po zabiegu chory został podłączony do respiratora na oddechu w trybie SIMV objętościowym. Odcinek szyjny kręgosłupa zabezpieczono kołnierzem Schanza.

W trakcie leczenia chory był kilkakrotnie ekstubowany i ponownie intubowany ze względu na narastające objawy niewydolności oddechowej. Odruch kaszlowy był osłabiony ze względu na porażenie. W drogach oddechowych utrzymywała się duża ilość wydzieliny, której pacjent nie był w stanie odkrztusić.

Ostatecznie wykonano zabieg tracheotomii. Po kilku tygodniach pacjent nie wymagał już wspomagania oddychania z użyciem respiratora. Okresowo zachodziła konieczność odsysania wydzieliny z dróg oddechowych. Chory był zaniepokojony brakiem samodzielności w odkrztuszaniu wydzieliny. Dodatkowym problemem było uczucie dyskomfortu spowodowane uciskiem tasiemki mocującej rurkę tracheotomijną. Pacjent zgłaszał uczucie duszności. Obawiał się, że rurka była nieprawidłowo założona.

Chory przejawiał lęk, gdy tracił opiekuna z pola widzenia. Domagał się zmiany pozycji ciała w kilkuminutowych odstępach. W nocy usiłował walczyć ze snem, ponieważ bał się, że personel nie zauważy u niego potencjalnych objawów zagrożenia życia.

Występowały objawy dezorientacji allopsychicznej. Chory był pobudzony. Nawiązanie logicznego kontaktu było niemożliwe.

Ze względu na niewydolność krążenia przez 4 dni utrzymywano wlew amin presyjnych Obserwowano liczne epizody napadowej bradykardii oraz jeden epizod napadowego częstoskurczu nadkomorowego (ok. 200/min) o niewyjaśnionej etiologii. W przebiegu hospitalizacji wystąpił epizod NZK w mechanizmie asystolii. Pacjent został skutecznie resuscytowany.

W trakcie pobytu na oddziale z pobranych wymazów z drzewa oskrzelowego wyhodowano: Pseudomonas aeruginosa, S. epidermidis, C. albicas, Acinetobacter haemoliticus. Zastosowano antybiotykoterapię celowaną.

W trakcie hospitalizacji pacjent początkowo odżywiany był przez sondę oraz okresowo całkowicie dożylnie. U chorego zaobserwowano zaburzenia przewodu pokarmowego spowodowane nie tylko urazem, ale też zastosowanym leczeniem i sposobem odżywiania. W wyniku podawania przemysłowych mieszanek na początku zaobserwowano brak perystaltyki jelit, a potem biegunki i smoliste stolce. Mimo stosowania zbilansowanego leczenia żywieniowego wystąpiły powikłania wynikające z niedożywienia: odleżyny w okolicy pasa biodrowego, spadek odporności, anemizacja.

Chory był konsultowany stomatologicznie, chirurgicznie i laryngologicznie. Zaobserwowano dodatkowe zaburzenia o typie hiponatremii oraz wielomocz. Pierwsze próby pionizacji były powikłane omdleniami. 
$\mathrm{W}$ dniu wypisu $\mathrm{z}$ oddziału intensywnej terapii pacjent był przytomny, w logicznym kontakcie. $Z$ powodu obecności rurki tracheotomijnej komunikował się za pomocą ruchu ust i bezgłośnego szeptu. Nie zgłaszał dolegliwości, nie gorączkował, był wydolny oddechowo, okresowo wymagał odsysania wydzieliny z dróg oddechowych. Odczuwał dotyk prawidłowo powyżej linii pępka, poniżej czucie dotyku było obecne, ale znacznie osłabione. Kończyny dolne pozostały porażone.

Był wydolny krążeniowo, ciśnienie tętnicze było stabilne. W kończynach górnych ruch był możliwy w obrębie pasa barkowego, siła i napięcie mięśniowe były osłabione.

W trakcie hospitalizacji uzyskano poprawę stanu neurologicznego w zakresie czucia i ruchomości kończyn górnych. Rana operacyjna została wygojona, pacjent przeszedł wstępny cykl leczenia rehabilitacyjnego. $Z$ dotychczasowych problemów utrzymywały się odleżyny, problemy ze snem, okresowa duszność i zaburzenia emocjonalne. W stanie ogólnym stabilnym chory został przekazany na oddział rehabilitacyjny celem dalszego leczenia.

Zalecenia, z którymi pacjent został wypisany z oddziału intensywnej terapii:

- pionizacja 4 razy dziennie, po uprzednim podaniu Effortilu aby nie dopuścić do spadków ortostatycznych ciśnienia tętniczego,

- utrzymywanie pozycji siedzącej przez okres jednej godziny dziennie, ze stopniowym wydłużaniem tego okresu,

- odsysanie wydzieliny z górnych dróg oddechowych,

- pielęgnacja rurki tracheotomijnej,

- podawanie leków doustnych.

Problemy pielęgnacyjne występujące u pacjenta podczas hospitalizacji w oddziale intensywnej terapii:

1. Trudności z utrzymaniem drożności dróg oddechowych z powodu dużej ilości gęstej, ropnej wydzieliny, zaburzone oddychanie aspiracja duszność spływanie wydzieliny do nosogardła, świszczenie , zaburzona czystość dróg oddechowych, zaburzona wymiana gazowa.

2. Ryzyko powikłań wynikających $z$ tracheotomii i wentylacji mechanicznej np. (aspiracja treści pokarmowej do dróg oddechowych, krwotok, zwężenie tchawicy, zakażenie, przetoka przełykowa).

3. Wzmożona potliwość związana z gorączką, zaburzona termoregulacja , brak równowagi elektrolitowej odwodnienie zaburzenie równowagi kwasowo-zasadowej.

4. Ryzyko wystąpienia powikłań naczyniowych z powodu założonego wkłucia centralnego i tętniczego (np. stan zapalny w miejscu wkłucia, zakrzepica w świetle cewnika).

5. Ryzyko wystąpienia zakażenia dróg moczowych $\mathrm{z}$ powodu cewnika założonego do pęcherza moczowego.

6. Ryzyko wystąpienia powikłań z powodu żywienia enteralnego np. zatkanie zgłębnika, zakażenie, nudności, wymioty, wzdęcia, biegunki.

7. Zaburzenia w komunikowaniu werbalnym $\mathrm{z}$ powodu założonej rurki tracheotomijnej, wentylacji mechanicznej i stosowanej sedacji.

8. Ryzyko wystąpienia powikłań z powodu unieruchomienia np. odparzenia, choroba zakrzepowo-zatorowa, zniekształcenia w stawach, zanik mięśni.
9. Deficyty w zakresie samopielęgnacji związane ze stanem zdrowia chorego, zaburzeniami świadomości, sztuczną wentylacją i stosowaną sedacją.

10. Zaburzenia emocjonalne.

11. Odleżyny w okolicy pasa biodrowego spowodowane niedożywieniem.

\section{PODSUMOWANIE}

Problemy pielęgnacyjne, które zostały przedstawione w pracy, występują u większości pacjentów po urazowym uszkodzeniu rdzenia kręgowego. Oprócz tego w opisanym przypadku wystąpiły problemy związane z zespołem stresu pourazowego (PTDS). Podczas pobytu w oddziale przez dłuższy czas odgrywały one dominującą rolę (lęk, bezsenność, zaburzenia pracy serca.). Wydaje się, że w oddziale intensywnej terapii nie kładzie się wystarczającego nacisku na sferę psychiczną chorego. Być może przyczyną jest brak dostatecznego przygotowania personelu pielęgniarskiego, zbyt mała obsada personalna oraz brak psychologów klinicznych.

Problemy dotyczące układu oddechowego wynikały z urazu kręgosłupa (płytkie oddechy i trudności z efektywnym kaszlem), a dodatkowym czynnikiem obciążającym był niedostateczny stan higieniczny jamy ustnej. Była to jedna z głównych przyczyn przedłużenia pobytu chorego w oddziale i eskalacji problemów terapeutycznych [6-14].

\section{PIŚMIENNICTWO/REFERENCES}

1. Krause JS, Carter R, Pickelsimer EE, et al. A prospective study of health and risk of mortality after spinal cord injury. Arch. Phys. Med. Rehabilit. 2008, 89(8): 1482-1491.

2. Schilero GJ, Spungen AM, Bauman WA, et al. Pulmonary function and spinal cord injury. Respiratory, Physiology\&Neurology. 2009: 166, 129-141.

3. Jaracz K, Kozubski W. Pielęgniarstwo neurologiczne. Podręcznik studiów medycznych. Warszawa: Wyd. Lekarskie PZWL; 2008, s. 421.

4. Noszczyk W. (red.). Chirurgia. Warszawa: Wyd. Lekarskie PZWL; 2005, s. 288-189.

5. Bilikiewicz A. (red.): Psychiatria kliniczna. Wrocław: Wydawnictwo Medyczne Urban \&Partner; 2002

6. Wołowicka L, Dyk D. Anestezjologia i intensywna opieka. Klinika i pielęgniarstwo. Podręcznik dla studiów medycznych. Warszawa: Wydawnictwo Lekarskie PZWL; 2014.

7. Dahm KT, Dalsbo TK, Kirkrhei I, Reinar LM. Effect of respiratory muscle training for acute traumatic high spinal cord injury: a systematic review. Report from the Norwegian Institute of Public Health; 2017.

8. Harkema SJ, Wang S, Angeli CA, et al. Normalization of blood pressure with spinal cord epidural stimulation after severe spinal cord injury. Front. Hum. Neurosci., 2018.

9. Strużyna J. Wczesne leczenie oparzeń. Warszawa: Wydawnictwo Lekarskie PZWL; 2006, s. 309-310.

10. Krajewska- Kułak E (red.), Rolka H, Jankowiak B. Standardy i procedury pielęgnowania chorych $w$ stanach zagrożenia życia. Podręcznik dla studiów medycznych. Warszawa: Wydawnictwo Lekarskie PZWL; 2009.

11. Szulc R. Usprawnianie lecznicze krytycznie chorych. Wrocław: Wydawnictwo Medyczne Urban \& Partner; 2001.

12. Kózka M. Stany zagrożenia życia. Wybrane standardy i procedury postępowania pielęgniarskiego. Kraków: Wydawnictwo UJ; 2001.

13. Krajewska-KułakE (red.), Rolka H, Jankowiak B. Standardy anestezjologicznej opieki pielęgniarskiej. Warszawa: PZWL; 2014.

14. Zarzycka D, Ślusarczyk B. Podręcznik diagnoz pielęgniarskich. Przewodnik planowania opieki opartej na dowodach naukowych. Warszawa: GCR Media House Sp. z 0.0.; 2011

Praca przyjęta do druku/Manuscript received:

03.03.2018

Praca zaakceptowana do druku/Manuscript accepted: 11.06.2018

Tłumaczenie/Translation: Dariusz Sochacki 